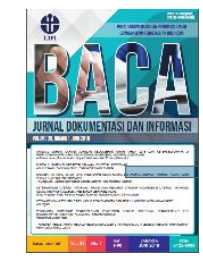

\title{
ANALISIS PENGELOLAAN PENGETAHUAN DENGAN ASIAN PRODUCTIVITY ORGANIZATION - ASSESSMENT TOOLS PADA PERUSAHAAN PERKEBUNAN INDONESIA
}

\author{
Muhammad Golfidi Djajasoedarma ${ }^{1 *}$, Anggraini Sukmawati ${ }^{2}$, \\ Elisa Anggraeni ${ }^{3}$ \\ ${ }^{1}$ Pascasarjana Ilmu Manajemen, Fakultas Ekonomi Manajemen - IPB \\ ${ }^{2}$ Departemen Manajemen, Fakultas Ekonomi Manajemen - IPB \\ ${ }^{3}$ Departemen Teknologi Industri Pertanian, Fakultas Teknologi Pertanian - IPB \\ *Korespondensi: muhammadgolfidi@gmail.com
}

Diajukan: 13-05-2019; Direview: 02-07-2019; Diterima: 09-09-2019; Direvisi: 01-01-2020

\begin{abstract}
Various changes that occur in the current business environment requires an organization/company to survive and adapt to various changes that occur in the business environment. So companies can survive in the business environment, they must innovate products, expand markets, improve service quality, improve production processes, improve organizational systems, and make cost savings. A company needs to view knowledge as a valuable and strategic resource. With good knowledge management, organizational resources are not easily imitated by business competitors. Knowledge management in this study uses the APO Assessment Tools framework to assess the maturity level of knowledge management of plantation companies. APO Assessment Tools have 7 categories, namely leadership, processes, people, technology, knowledge processes, learning and innovation, and the results of knowledge management. The results showed that knowledge management in plantation companies in Indonesia was approaching maturity.
\end{abstract}

\begin{abstract}
ABSTRAK
Berbagai perubahan yang terjadi dalam lingkungan usaha saat ini menuntut suatu organisasi/perusahaan dapat bertahan dan beradaptasi dengan berbagai perubahan yang terjadi di lingkungan usaha. Agar perusahaan dapat bertahan dalam lingkungan usaha maka harus melakukan inovasi produk, memperluas pasar, meningkatkan kualitas layanan, meningkatkan proses produksi, meningkatkan sistem organisasi, dan melakukan penghematan biaya. Suatu perusahaan perlu memandang pengetahuan sebagai sumber daya yang berharga dan strategis. Dengan pengelolaan pengetahuan yang baik, sumber daya organisasi tidak mudah ditiru oleh kompetitor usaha. Manajemen pengetahuan pada penelitian ini menggunakan kerangka $A P O$ Assessment Tools untuk menilai tingkat kematangan manajemen pengetahuan perusahaan perkebunan. APO Assesment Tools ini memiliki 7 kategori, yaitu kepemimpinan, proses, orang, teknologi, proses pengetahuan, pembelajaran dan inovasi, dan hasil pengelolaan pengetahuan. Hasil penelitian menunjukkan bahwa pengelolaan pengetahuan pada perusahaan perkebunan di Indonesia sudah dalam tahap mendekati kematangan.
\end{abstract}

Keywords: Knowledge management; Asian productivity organization; Assessment tools; Organization; Indonesia

\section{PENDAHULUAN}

Pengetahuan organisasi menjadi kunci sukses dalam meningkatkan kinerja perusahaan dan keunggulan tersendiri dalam melaksanakan usahanya. Sebuah perusahaan tidak cukup hanya belajar saja, tetapi juga harus mampu beradaptasi dengan perubahan yang terjadi dilingkungannya. North \& Kumta (2018) mengatakan bahwa seperangkat pengetahuan dan kompetensi spesifik yang dimiliki organisasi atau perusahaan dapat mendukung mereka dalam 
menawarkan produk dan jasa yang berbeda (unik) dari pesaing usaha lainnya. Selain itu, dapat meningkatkan efektivitas operasional perusahaan dalam menciptakan nilai tambah kepada konsumen.

Dalam proses penggunaan pengetahuan pada manajemen perusahaan, tentunya ada beberapa hal yang menjadi kendala/tantangan dari lingkungannya, untuk itu perlu ada pengelolaan pengetahuan (knowledge management) yang baik dalam perusahaan tersebut. Pengelolaan pengetahuan menjadi dasar para pegawai/staf perusahaan dalam melaksanakan tugas dan tanggung jawabnya. Penelitian ini membahas tentang pengelolaan pengetahuan suatu organisasi, khususnya pada tingkat kematangan pengelolaan pengetahuan dengan menggunakan Asian Productivity Organization (APO) Assessment Tools.

APO Assessment Tools dapat menjelaskan kondisi perusahaan secara menyeluruh dan melihat langkah-langkah pertumbuhan organisasi, serta mendukung pengembangan pengelolaan pengetahuan dan kinerja organisasi (Khatibian, et al, 2010; Naser, et al., 2016). APO Assessment Tools juga dapat menentukan tahapan kematangan pengetahuan suatu organisasi, menyebarkan pengetahuan, serta meningkatkan keunggulan kompetitif dan kinerja organisasi secara keseluruhan (Sensuse \& Rohajawati, 2013).

\section{TINJAUAN PUSTAKA}

\subsection{Pengelolaan Pengetahuan}

Rusilowati (2015) menjelaskan bahwa pengetahuan manusia dimulai sejak manusia mengenal informasi, kemudian informasi yang didapat selanjutnya diteruskan kepada orang lain melalui komunikasi, baik secara langsung maupun tidak langsung. Kemudian pengetahuan dan informasi bergerak secara dinamis melalui organisasi dalam berbagai cara, tergantung dari cara pandang organisasi yang bersangkutan. Menurut Nonaka \& Takeuchi (1995), pengetahuan dapat menjadi sebuah sumberdaya yang sangat berarti bagi organisasi/perusahaan. Pengetahuan suatu organisasi memiliki keunggulan untuk persaingan usaha, dan menjadi modal kepemimpinan suatu organisasi/perusahaan. Menurut Nonaka, et al. (2013), organisasi atau perusahaan juga harus dapat menciptakan pengetahuan baru yang bersifat inovatif dalam mendukung kegiatan usaha yang bersangkutan Manajemen pengetahuan diharapkan dapat menjadi sekumpulan perangkat, teknik, dan strategi dalam mempertahankan, menganalisis, mengorganisasi, meningkatkan, dan membagikan pengertian dan pengalaman. Pengetahuan dapat menjadi sumber kompetitif bagi organisasi, sumber kekuatan, dan sumber keunggulan bersaing - memiliki peran yang sangat strategis bagi organisasi khususnya di era teknologi informasi (Jane, 2009).

Pengelolaan pengetahuan atau manajemen pengetahuan sangat terkait erat dengan pengetahuan yang dimiliki oleh seorang karyawan (Sedarmayanti, 2017). Beberapa hal yang menyebabkan pengelolaan pengetahuan sangat penting bagi organisasi, yaitu: (1) membantu organisasi untuk menilai, mengukur, dan mengidentifikasi kesenjangan pengetahuan yang mereka miliki; (2) menentukan dampak kesenjangan pengetahuan pada kinerja, pertumbuhan dan pengembangan dari organisasi yang bersangkutan; (3) membantu pengelolaan pengetahuan suatu organisasi secara efisien; (4) menyediakan alat analisis bagi organisasi untuk mengatasi kesenjangan pengetahuan; (5) mengidentifikasi strategi dan kegiatan yang tepat untuk memperbaiki kesenjangan dalam hal pengetahuan (Vestal, 2002; O'Brien, 2013; Hoss \& Schlussel, 2009). Emilisa et al. (2017) mengatakan manajemen pengetahuan ada keterkaitan dalam hal proses dan kinerja manajemen pengetahuan itu sendiri. Manajemen pengetahuan merupakan rangkaian kegiatan yang digunakan oleh perusahaan untuk 
mengidentifikasi, menciptakan, menjelaskan, dan mendistribusikan pengetahuan untuk digunakan kembali, diketahui, dan dipelajari oleh pegawai yang bekerja dalam perusahaan yang bersangkutan.

Nonaka \& Takeuchi dalam North \& Kumta (2018) membagi pengetahuan menjadi dua, yaitu: pengetahuan explicit dan pengetahuan tacit. Pengetahuan tacit mewakili pengetahuan pribadi dari seorang individu. Hal ini didasarkan pada pendidikan, cita-cita, nilai-nilai dan perasaan orang perseorangan. Sedangkan, pengetahuan explicit lebih bersifat metode dan sistematik, serta hadir dalam bentuk yang telah diartikulasikan. Hal ini dikelola dalam pemikiran seorang individu yang dapat ditransfer dan disimpan dengan adanya penggunaan teknologi informasi dan komunikasi. Pengetahuan diciptakan melalui interaksi antara pengetahuan tacit dan explicit yang melalui empat proses, yaitu socialization, externalization, combination, internalization (Nonaka \& Takeuchi, 1995).

- Sosialisasi - kegiatan berbagi pengalaman dalam interaksi sosial yang terjadi antara individu satu dengan individu yang lainnya sehingga terjadi pertukaran informasi melalui kegiatan yang dilakukan secara bersama.

- Eksternalisasi - mengartikulasikan pengetahuan tacit menjadi explicit. Hal ini terjadi ketika seorang individu mendeskripsikan suatu proses untuk mencapai tujuan yang ingin dicapai melalui suatu konsep maupun hipotesis yang dapat dipahami oleh pihak lain.

- Kombinasi - mengacu pada konversi pengetahuan explicit ke explicit. Setiap individu saling bertukar informasi dan pengetahuan melalui berbagai dokumen, kegiatan rapat maupun jaringan komunikasi.

- Internalisasi - mewujudkan pengetahuan explicit ke dalam pengetahuan tacit. Hal ini terkait erat dengan pembelajaran yang dilakukan dengan kegiatan secara langsung, yang bertujuan untuk memperluas, memperdalam, serta mengubah pengetahuan tacit yang dimiliki oleh setiap anggota suatu organisasi menjadi pengetahuan yang dimiliki oleh perusahaan yang bersangkutan.

\subsection{APO Assessment Tools}

Menurut Shaikh, et al. (2009), faktor kunci dari organisasi yang sukses, yaitu adanya proses pengukuran dan penilaian sumber daya yang dimiliki dalam menjalankan kegiatan usaha. APO Assessment Tools dapat digunakan untuk mengukur dan menilai kinerja organisasi berbasis pengetahuan, sebagaimana dikatakan Sveiby (2001), bahwa: (1) pengetahuan menjadi kunci pengembangan inovasi; (2) kesuksesan manajemen pengetahuan di berbagai institusi dan praktisi di negara Eropa dan Amerika telah memicu pada ahli di negara Asia untuk membuat kerangka kerja manajemen pengetahuan dari APO; (3) para ahli membangun kerangka kerja manajemen pengetahuan APO berdasarkan pengalaman terbaik dari Amerika, Australia, dan Eropa. Tujuan dari kerangka kerja APO adalah untuk memberikan pengetahuan umum di antara negara-negara Asia dan menekankan nilai dari pengelolaan pengetahuan untuk kesuksesan suatu organisasi (Sensuse \& Rohajawati 2013). Gambar 1 merupakan kerangka umum APO Assessment Tools. 


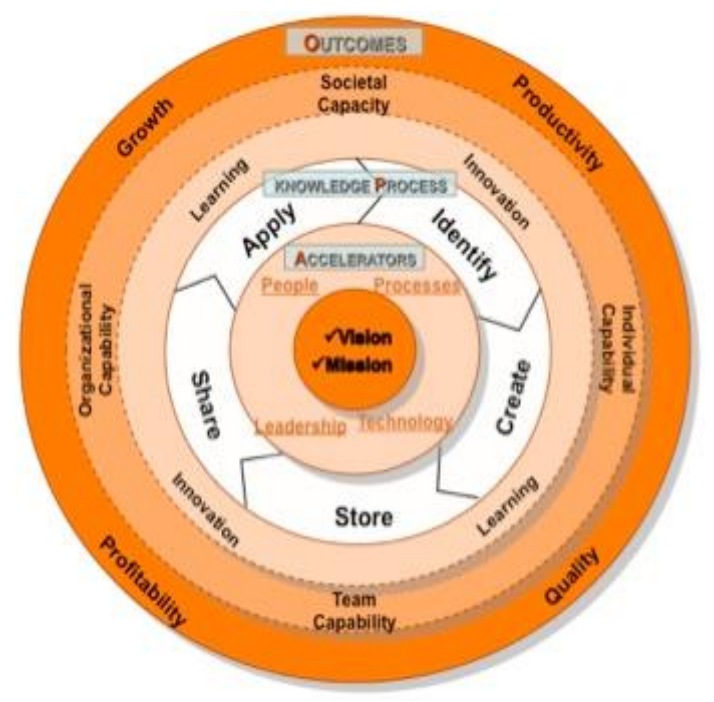

Gambar 1. Kerangka Umum APO Assessment Tools (Young, 2010)

Menurut Hubert, et al. (2010) \& Naser, et al. (2016), model kematangan dari pengelolaan pengetahuan menjelaskan kondisi umum suatu organisasi yang telah dilalui dalam melaksanakan usahanya. Kerangka kerja APO di atas menjelaskan beberapa tingkatan kategori kematangan dalam manajemen pengetahuan, yang dimulai dari: (1) visi dan misi organisasi, yang menggambarkan strategi dan kemampuan yang dimiliki oleh organisasi; (2) faktor-faktor yang dapat mempercepat proses pengelolaan pengetahuan organisasi, seperti kepemimpinan, teknologi, proses, maupun individu/pegawai suatu perusahaan; (3) penerapan manajemen pengetahuan organisasi, dari sisi kualitas, produktivitas, keuntungan, dan perkembangan perusahaan.

\section{METODE}

Penelitian ini menggunakan teknik literature review, khususnya yang terkait bidang penilaian APO Assessment Tools, yaitu: (1) kepemimpinan dalam manajemen pengetahuan; (2) proses; (3) orang yang diteliti; (4) teknologi; (5) proses pengetahuan yang ada; (6) proses belajar dan inovasi; (7) hasil penerapan manajemen pengetahuan (Young, 2010). Ketujuh hal tersebut diidentifikasi inisiatif pengelolaan pengetahuannya. Hasil penilaian akan menyoroti kekuatan dan bidang kerja untuk peningkatan kinerja organisasi secara keseluruhan melalui pengelolaan pengetahuan. Selain literature review, penelitian ini menggunakan kuesioner yang disebarkan kepada responden, untuk menjawab pertanyaan terkait tujuh bidang penilaian di atas. Kuesioner berisi 42 pertanyaan dengan nilai maksimum 210. Setiap kategori memiliki skor maksimum 30, dan setiap pertanyaan dinilai $1-5$ (sangat buruk - sangat baik). Hal tersebut dijelaskan pada Tabel 1.

Tabel 1. Daftar Penilaian Kuesioner

\begin{tabular}{|l|c|}
\hline \multicolumn{1}{|c|}{ Uraian } & $\begin{array}{c}\text { Skala } \\
\text { Penilaian }\end{array}$ \\
\hline Melakukan dengan sangat buruk atau tidak melakukan sama sekali & 1 \\
\hline Melakukan dengan buruk & 2 \\
\hline Melakukan dengan cukup & 3 \\
\hline Melakukan dengan baik & 4 \\
\hline Melakukan dengan sangat baik & 5 \\
\hline
\end{tabular}

Sumber: Ramadhani, et al. (2012) 
Responden yang menjawab kuesioner diharapkan mencapai $70-80 \%$ dari jumlah karyawan di perusahaan perkebunan yang diteliti. Kriteria ini ditetapkan agar dapat mengakomodir keseluruhan tingkat dan unit kerja responden yang diteliti. Selain itu, masa kerja karyawan yang dijadikan responden juga minimal telah bekerja selama 6 bulan (Young, 2010). Hal ini dilakukan agar responden memahami organisasinya dan dapat menjawab keseluruhan pertanyaan kuesioner. Nilai rata-rata yang diperoleh setiap kategori disajikan dalam bentuk grafik (Gambar 2).
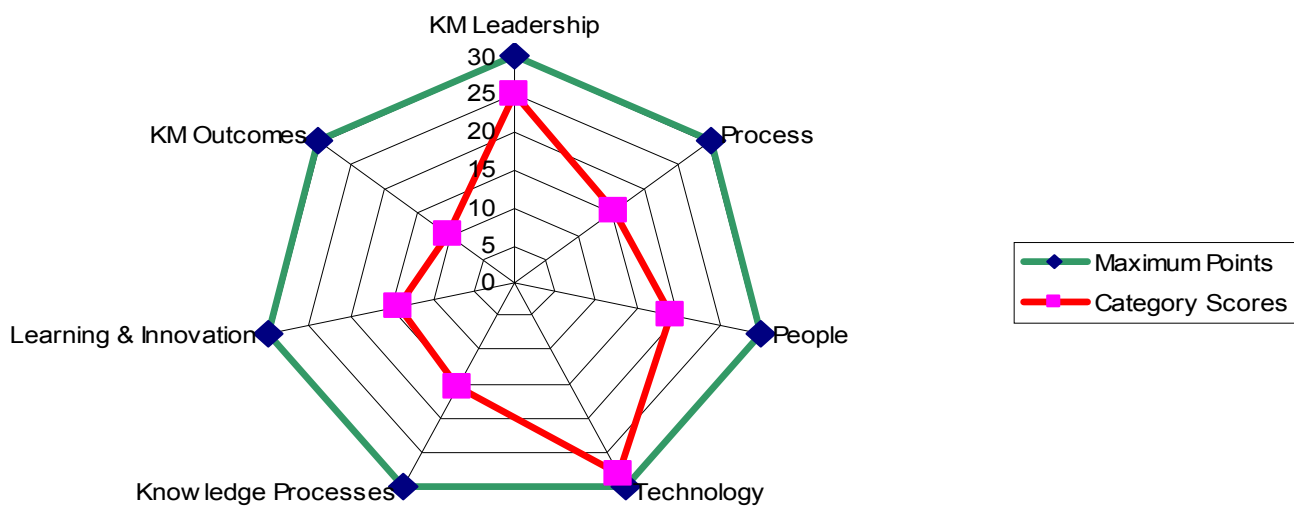

Gambar 2. Grafik radar (Naser, et al., 2016)

Grafik tersebut menunjukkan nilai aktual yang diperoleh untuk setiap kategori versus skor maksimum untuk kategori tersebut. Nilai yang terdapat pada grafik menunjukkan kategori yang sehat dan yang membutuhkan perbaikan.

Nilai ini diperoleh dari total nilai setiap kategori memiliki 6 pertanyaan, dengan total 42 pertanyaan kuesioner. Tingkat terendah penilaian pengelolaan pengetahuan dilihat dari total nilai dari keseluruhan 42 pertanyaan pada kisaran $42-83$ (reaction). Kemudian tingkat tertingginya dilihat dari total nilai yang diperoleh pada kisaran $189-210$. Nilai total yang diperoleh pada kuesioner kemudian dibandingkan dengan Model KM Maturity sebagaimana terlihat pada Gambar 3.

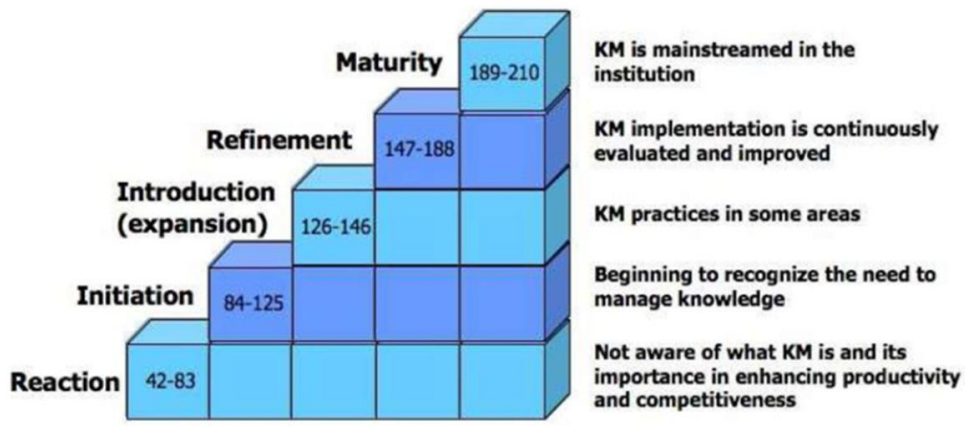

Gambar 3. KM Maturity (Al Shobaki, et al. 2016)

Gambar 3 menjelaskan bahwa kriteria penilaian pengelolaan pengetahuan dapat dilihat berdasarkan perbandingan tingkat kesadaran responden terhadap pentingnya pengelolaan pengetahuan bagi organisasi. Hasil penilaian memberikan pemahaman tentang tingkat kesiapan pengelolaan pengetahuan dalam suatu organisasi. Hal ini dapat berkisar mulai dari tingkat "reaksi" pada tingkat terendah dan hingga tingkat "kedewasaan" tertinggi. Kondisi 
yang menggambarkan masing-masing level ini sebenarnya terkait dengan kehadiran, ketidakhadiran, atau kelemahannya dari empat akselerator pengelolaan pengetahuan, pembelajaran dan inovasi, dan hasil kegiatan pengelolaan pengetahuan organisasi. Data hasil literature review dan kuesioner menjadi bahan pembahasan dan kesimpulan penelitian.

\section{HASIL DAN PEMBAHASAN}

\subsection{Tanggapan Responden Terhadap Pengelolaan Pengetahuan Organisasi}

Suatu organisasi dalam menjalankan usahanya tentunya harus berfokus pada pengelolaan sumber daya yang semakin efektif dan efisien guna menghasilkan produk yang kompetitif dan ramah lingkungan. Pengelolaan sumber daya organisasi perlu memperhatikan faktor lingkungan serta dampak sosial dan ekonomi bagi masyarakat sekitar, seperti: penggunaan dan pengelolaan material, energi, dan air; pengelolaan limbah padat dan cair; keselamatan dan kecelakaan kerja; hubungan dengan masyarakat; serta perekonomian masyarakat. Agar hal-hal tersebut dapat terlaksana dengan baik, organisasi perlu mengukur tingkat keberhasilan dengan entitas bisnis, seperti aspek finansial - mampu memberikan keuntungan kepada pemegang saham; masyarakat sekitar dapat menikmati manfaat atas keberadaan perusahaan; atau proses bisnisnya berdampak positif pada peningkatan kualitas hidup masyarakat sekitar.

Melalui kerangka kerja APO Assessment Tools tersebut, organisasi dapat menilai kondisi dan kekuatan pengetahuannya, sebagaimana tujuh bidang penilaian pengelolaan pengetahuan yang dikatakan oleh Young (2010), yakni sebagai berikut.

1) Kepimpinan - kategori ini mengevaluasi kapabilitas kepemimpinan organisasi untuk menanggapi tantangan ekonomi berbasis pengetahuan. Kepemimpinan ini terkait dengan kebijakan pengelolaan pengetahuan dan strategi yang ada di organisasi. Kepemimpinan ini menjadi dasar untuk memulai, membimbing, dan mempertahankan praktik pengelolaan pengetahuan organisasi.

2) Proses - kategori ini menilai bagaimana pengetahuan digunakan untuk mengelola, menerapkan, dan meningkatkan proses kerja utama organisasi. Proses ini juga menjadi dasar penilaian sejauh mana organisasi terus mengevaluasi dan meningkatkan proses kerjanya untuk mencapai kinerja yang lebih baik.

3) Orang - kategori ini fokus pada upaya organisasi untuk mendorong berbagi pengetahuan dan kolaborasi antar-orang perlu dievaluasi, termasuk pengembangan pekerja pengetahuan yang ada di organisasi tersebut.

4) Teknologi - kategori ini meninjau kemampuan organisasi untuk mengembangkan dan memberikan solusi berbasis teknologi, seperti alat kolaboratif dan sistem manajemen informasi. Keandalan dan aksesibilitas teknologi yang digunakan untuk menjalankan fungsi organisasi juga perlu dievaluasi secara berkala, apakah masih relevan atau tidak.

5) Proses pengetahuan (identify, create, store, share, apply) - kategori ini terkait dengan kemampuan organisasi untuk mengidentifikasi, membuat, menyimpan, berbagi, dan menerapkan pengetahuan secara sistematis dievaluasi. Berbagi praktik terbaik dan pelajaran yang diambil untuk meminimalkan penciptaan kembali dan duplikasi kerja yang pernah dilakukan sebelumnya juga dinilai - sehingga efisiensi dan efektivitas kerja dapat tercapai dengan optimal sesuai dengan rencana kerja.

6) Proses belajar dan inovasi (individual, team, organizational, societal) - kategori ini menentukan kemampuan organisasi untuk mendorong, mendukung, dan memperkuat pembelajaran dan inovasi melalui proses pengetahuan yang sistematis. 
7) Hasil penerapan manajemen pengetahuan (productivity, quality, profitability, growth) kategori ini mengukur kemampuan organisasi untuk meningkatkan nilai kepada pelanggan melalui produk dan layanan baru yang lebih baik. Kemampuan organisasi untuk meningkatkan produktivitas, kualitas, profitabilitas, dan mempertahankan pertumbuhan melalui penggunaan sumber daya yang efektif dan sebagai hasil dari pembelajaran dan inovasi juga perlu dievaluasi.

Ketujuh bidang penilaian APO Assessment Tools kemudian diolah dengan nilai kuesioner (Tabel 1) dan dijabarkan dengan grafik radar (Gambar 2). Berdasarkan model KM Maturity (Gambar 3) dilakukan penelitian pada salah satu perusahaan perkebunan di Indonesia dengan menggunakan kuesioner, dan hasilnya ada 100 responden yang mengisi kuesioner (Tabel 2).

Tabel 2 . Hasil Penilaian Total Responden

\begin{tabular}{|c|c|c|}
\hline $\begin{array}{c}\text { KM Maturity } \\
\text { Level }\end{array}$ & Nilai & $\begin{array}{c}\text { Frekuensi } \\
(\mathrm{n}=100)\end{array}$ \\
\hline Kematangan & $189-210$ & $8 \%$ \\
\hline Perbaikan & $147-188$ & $42 \%$ \\
\hline Ekspansi & $126-146$ & $24 \%$ \\
\hline Inisiasi & $84-125$ & $25 \%$ \\
\hline Reaksi & $42-83$ & $1 \%$ \\
\hline \multicolumn{2}{|c|}{ Total } & $100 \%$ \\
\hline
\end{tabular}

Tabel 2 menunjukkan bahwa mayoritas responden menilai tingkat kematangan perusahaan pada tingkat perbaikan. Artinya bahwa manajemen pengetahuan yang ada perlu dievaluasi secara berkelanjutan untuk meningkatkan kinerja organisasi.

Kemudian untuk mendukung hasil penilaian semua responden, dilakukan perhitungan data berdasarkan jenis kelamin, usia, pendidikan, masa kerja, dan posisi karyawan. Berdasarkan jenis kelamin responden diketahui bahwa penghitungan dengan APO Assessment Tools menunjukkan bahwa tidak berbeda secara signifikan antara laki-laki dan perempuan dalam pengelolaan pengetahuan (Tabel 3).

Tabel 3. Pengolahan Data Berdasarkan Jenis Kelamin

\begin{tabular}{|c|c|c|c|}
\hline $\begin{array}{c}\text { KM Maturity } \\
\text { Level }\end{array}$ & Nilai & $\begin{array}{c}\text { Laki-Laki } \\
(\mathrm{n}=81)\end{array}$ & $\begin{array}{c}\text { Perempuan } \\
(\mathrm{n}=19)\end{array}$ \\
\hline Kematangan & $189-210$ & $7 \%$ & $11 \%$ \\
\hline Perbaikan & $147-188$ & $42 \%$ & $42 \%$ \\
\hline Ekspansi & $126-146$ & $24 \%$ & $26 \%$ \\
\hline Inisiasi & $84-125$ & $26 \%$ & $21 \%$ \\
\hline Reaksi & $42-83$ & $1 \%$ & $0 \%$ \\
\hline Total & $100 \%$ & $100 \%$ \\
\hline
\end{tabular}

Tabel 3 menunjukkan bahwa jumlah responden lebih banyak karyawan laki-laki dari pada perempuan, sehingga beban kerja mereka pun juga berbeda.

berdasarkan usia responden diketahui bahwa hasil penghitungan APO Assessment Tools menunjukkan bahwa tingkat kematangan setiap usia responden berada pada tingkat perbaikan (Tabel 4). 
Tabel 4. Pengolahan Data Berdasarkan Usia

\begin{tabular}{|c|c|c|c|c|c|}
\hline $\begin{array}{c}\text { KM Maturity } \\
\text { L evel }\end{array}$ & Nilai & $\begin{array}{c}<30 \text { tahun } \\
(\mathrm{n}=1)\end{array}$ & $\begin{array}{c}30-40 \text { th } \\
(\mathrm{n}=48)\end{array}$ & $\begin{array}{c}41-50 \text { th } \\
(\mathrm{n}=34)\end{array}$ & $\begin{array}{c}>50 \text { tahun } \\
(\mathrm{n}=17)\end{array}$ \\
\hline Kematangan & $189-210$ & $0 \%$ & $4 \%$ & $12 \%$ & $12 \%$ \\
\hline Perbaikan & $147-188$ & $100 \%$ & $40 \%$ & $38 \%$ & $53 \%$ \\
\hline Ekspansi & $126-146$ & $0 \%$ & $33 \%$ & $18 \%$ & $12 \%$ \\
\hline Inisiasi & $84-125$ & $0 \%$ & $23 \%$ & $29 \%$ & $23 \%$ \\
\hline Reaksi & $42-83$ & $0 \%$ & $0 \%$ & $3 \%$ & $0 \%$ \\
\hline \multicolumn{2}{r|}{ Total } & $100 \%$ & $100 \%$ & $100 \%$ & $100 \%$ \\
\hline
\end{tabular}

Tabel 4 menunjukkan bahwa sebagian besar responden dalam kisaran usia 30 - 40 tahun yang memiliki tingkat kematangan pengetahuan organisasi.

Berdasarkan tingkat pendidikan responden diketahui bahwa hasil pengolahan APO Assessment Tools menunjukkan bahwa sebagian besar responden memiliki latar belakang pendidikan "diploma" - pengelolaan pengetahuan pada tingkat inisiasi (Tabel 5). Mereka menyadari bahwa pengelolaan pengetahuan itu penting dan diperlukan untuk mendukung kegiatan organisasi.

Tabel 5. Pengolahan Data Berdasarkan Pendidikan

\begin{tabular}{|c|c|c|c|c|c|}
\hline KM Maturity Level & Nilai & $\begin{array}{c}\text { SMA } \\
(\mathrm{n}=15)\end{array}$ & $\begin{array}{c}\text { Diploma } \\
(\mathrm{n}=5)\end{array}$ & $\begin{array}{c}\text { Bujangan } \\
(\mathrm{n}=70)\end{array}$ & $\begin{array}{c}\text { Pascasarjana } \\
(\mathrm{n}=10)\end{array}$ \\
\hline Kematangan & $189-210$ & $26 \%$ & $0 \%$ & $3 \%$ & $20 \%$ \\
\hline Perbaikan & $147-188$ & $60 \%$ & $20 \%$ & $41 \%$ & $30 \%$ \\
\hline Ekspansi & $126-146$ & $7 \%$ & $20 \%$ & $29 \%$ & $20 \%$ \\
\hline Inisiasi & $84-125$ & $7 \%$ & $60 \%$ & $26 \%$ & $30 \%$ \\
\hline Reaksi & $42-83$ & $0 \%$ & $0 \%$ & $1 \%$ & $0 \%$ \\
\hline Total & $100 \%$ & $100 \%$ & $100 \%$ & $100 \%$ \\
\hline
\end{tabular}

Tabel 5 menunjukkan sebagian besar responden menilai bahwa manajemen pengetahuan yang telah ada di organisasi perkebunan berada pada tingkat perbaikan. Beberapa responden dari pascasarjana dan diploma ada yang menganggap bahwa manajemen pengetahuan organisasi masih pada tingkat inisiasi.

Tabel 6. Pengolahan Data Berdasarkan Masa Kerja

\begin{tabular}{|c|c|c|c|c|c|}
\hline KM Maturity Level & Nilai & $\begin{array}{c}5-10 \text { tahun } \\
(\mathrm{n}=40)\end{array}$ & $\begin{array}{c}11-15 \text { tahun } \\
(\mathrm{n}=12)\end{array}$ & $\begin{array}{c}16-20 \\
(\mathrm{n}=21)\end{array}$ & $\begin{array}{c}>20 \text { tahun } \\
(\mathrm{n}=27)\end{array}$ \\
\hline Kematangan & $189-210$ & $3 \%$ & $0 \%$ & $10 \%$ & $19 \%$ \\
\hline Perbaikan & $147-188$ & $40 \%$ & $33 \%$ & $29 \%$ & $59 \%$ \\
\hline Ekspansi & $126-146$ & $35 \%$ & $33 \%$ & $19 \%$ & $7 \%$ \\
\hline Inisiasi & $84-125$ & $22 \%$ & $34 \%$ & $38 \%$ & $15 \%$ \\
\hline Reaksi & $42-83$ & $0 \%$ & $0 \%$ & $4 \%$ & $0 \%$ \\
\hline \multicolumn{2}{r|}{ Total } & $100 \%$ & $100 \%$ & $100 \%$ & $100 \%$ \\
\hline
\end{tabular}

Tabel 6 menunjukkan bahwa tingkat pengelolaan pengetahuan berada di tingkat perbaikan, sebagaimana yang dikatakan oleh karyawan dengan masa kerja lebih dari 20 tahun bahwa mereka memiliki kematangan berorganisasi yang lebih baik daripada mereka yang bekerja kurang dari 20 tahun. 
Tabel 7. Pengolahan Data Berdasarkan Posisi Karyawan

\begin{tabular}{|c|c|c|c|c|c|}
\hline KM Maturity Level & Nilai & $\begin{array}{c}\text { Mandor } \\
(\mathrm{n}=10)\end{array}$ & $\begin{array}{c}\text { Staf } \\
(\mathrm{n}=74)\end{array}$ & $\begin{array}{c}\text { Kepala } \\
\text { Subbagian } \\
(\mathrm{n}=14)\end{array}$ & $\begin{array}{c}\text { Manajer } \\
(\mathrm{n}=2)\end{array}$ \\
\hline Kematangan & $189-210$ & $40 \%$ & $4 \%$ & $7 \%$ & $0 \%$ \\
\hline Perbaikan & $147-188$ & $60 \%$ & $42 \%$ & $36 \%$ & $0 \%$ \\
\hline Ekspansi & $126-146$ & $0 \%$ & $30 \%$ & $7 \%$ & $50 \%$ \\
\hline Inisiasi & $84-125$ & $0 \%$ & $23 \%$ & $50 \%$ & $50 \%$ \\
\hline Reaksi & $42-83$ & $0 \%$ & $1 \%$ & $0 \%$ & $0 \%$ \\
\hline Total & $100 \%$ & $100 \%$ & $100 \%$ & $100 \%$ \\
\hline
\end{tabular}

Tabel 7 menunjukkan bahwa tingkat kematangan untuk posisi mandor dan staf berada pada tingkat perbaikan, mereka pada tingkat yang lebih "dewasa" jika dibandingkan dengan posisi kepala subbagian dan manajer.

\subsection{Penilaian Kategori Berdasarkan APO Assessment Tools}

Penilaian kategori hasil APO Assessment Tools berdasarkan nilai rata-rata pada setiap kategori yang dijelaskan melalui grafik radar (Gambar 4). Data grafik radar bersumber dari nilai rata-rata dari jawaban 100 responden pada setiap pernyataan kategori. Hasilnya dapat dilihat pada Tabel 8 .

Tabel 8. Nilai Rata-Rata Kategori

\begin{tabular}{|l|c|c|}
\hline \multicolumn{1}{|c|}{ Kategori } & $\begin{array}{c}\text { Nilai } \\
\text { Maksimum }\end{array}$ & $\begin{array}{c}\text { Nilai Rata-Rata } \\
\text { Kategori }\end{array}$ \\
\hline 1.0 (KM Leadership) & 30 & 20.85 \\
\hline 2.0 ( Process $)$ & 30 & 21,51 \\
\hline 3.0 ( People) & 30 & 20.70 \\
\hline 4.0 ( Technology) & 30 & 21.43 \\
\hline 5.0 ( Knowledge Processes ) & 30 & 20.40 \\
\hline 6.0 ( Learning \& Innovation) & 30 & 20.34 \\
\hline 7.0 (KM Outcomes $)$ & 30 & 20,62 \\
\hline Total & 210 & 145.85 \\
\hline
\end{tabular}

Berdasarkan Tabel 8, setiap kategori digambarkan melalui grafik radar berikut ini (Gambar 4).

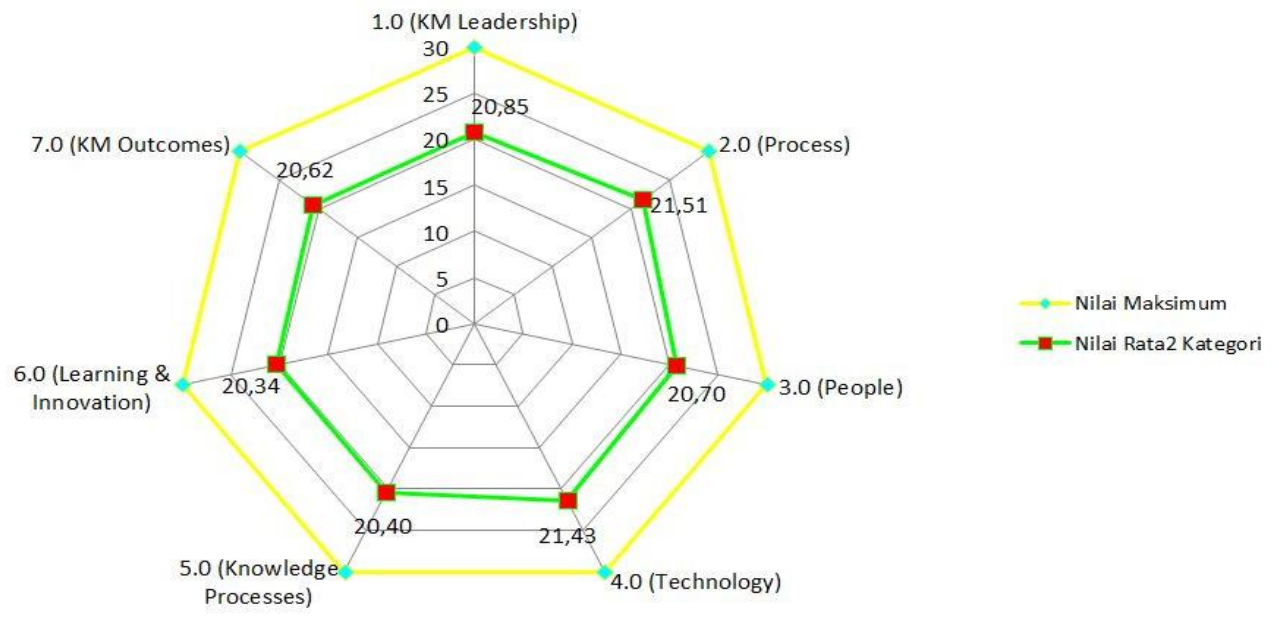

Gambar 4. Grafik radar nilai rata-rata setiap kategori 
Berdasarkan Gambar 4 dapat dijelaskan sebagai berikut.

- Nilai tertinggi dari pengelolaan pengetahuan perusahaan perkebunan terdapat pada kategori 2.0 (Proses) dengan nilai rata-rata 21,51, dan diikuti oleh kategori 4.0 (Teknologi) dengan nilai rata-rata 21,43. Hal tersebut menunjukkan bahwa perusahaan telah melakukan proses pengelolaan pengetahuan berdasarkan dukungan sistem teknologi informasi.

- Pada kategori lain, seperti KM Leadership, People, dan KM Outcomes memiliki nilai yang sama (sekitar 21) - menunjukkan bahwa: (1) nilai rata-rata berada dalam kriteria "cukup baik" atau karyawan di perusahaan tersebut "cukup percaya diri" dengan pemimpin mereka; (2) kemampuan organisasi dalam menciptakan pengetahuan dan mempertahankan "budaya pembelajaran" berbasis organisasi perlu diperhatikan; (3) upaya kolaborasi pengetahuan antar-karyawan perlu dievaluasi guna peningkatan kinerja organisasi; (4) perlunya evaluasi dalam peningkatan nilai produk dan layanan kepada pelanggan.

- Nilai rata-rata terendah berada pada kategori Knowledge Processes dan Learning and Innovation, yaitu sebesar 20,40 dan 20,34. Hal tersebut menunjukkan bahwa masih perlu dilakukan proses pembelajaran dan inovasi, terkait pengembangan pengetahuan dan sistem informasi perusahaan. Hal tersebut juga sesuai dengan penilaian responden (Tabel 2) yang menunjukkan bahwa pengelolaan pengetahuan perusahaan masih pada tingkat perbaikan (nilai rata-rata kategori sebesar 145,85) dan masih pada tingkat ekspansi (Tabel 3).

Berdasarkan hal di atas, hasil penilaian pengelolaan pengetahuan pada kondisi aktual berdasarkan hasil survei APO Assessment Tools dijelaskan sebagai berikut.

1) KM Leadership

- Penjelasan APO: manajemen perusahaan mengarahkan pelaksanaan pengelolaan pengetahuan.

- Hasil survei: kewajiban memberikan informasi dan pengetahuan tentang aktivitas perusahaan, mulai dari karyawan yang aktif hingga menjelang pensiun.

2) Process

- Penjelasan APO: proses pengelolaan pengetahuan di perusahaan perlu dievaluasi, untuk perbaikan kinerja organisasi di masa depan

- Hasil survei: kewajiban memberikan informasi dan pengetahuan tentang aktivitas perusahaan, mulai dari karyawan yang aktif hingga menjelang pensiun.

3) People

- Penjelasan APO: karyawan bertukar informasi dan pengetahuan tentang hal-hal yang kurang dimengerti ketika beraktivitas di tempat kerja.

- Hasil survei: tersedianya forum pelatihan dan pertemuan yang difasilitasi oleh perusahaan, serta peningkatan kerjasama antar-karyawan dalam pelaksanaan program kerja perusahaan.

4) Technology

- Penjelasan APO: peningkatan fasilitas teknologi untuk memudahkan karyawan dalam akses informasi via-internet/intranet.

- Hasil survei: karyawan terbantu dengan fasilitas teknologi dan sistem informasi untuk mendukung pekerjaan mereka. 


\section{5) Knowledge Process}

- Penjelasan APO: proses pengetahuan, seperti mengidentifikasi, membuat, menyimpan, berbagi, dan menerapkan pengetahuan bersama dalam proses pembelajaran dan inovasi telah dilakukan dengan baik, namun masih perlu sosialisasi secara masif dan komprehensif.

- Hasil survei: beberapa karyawan tidak memahami proses pengembangan pengetahuan, sistem informasi, dan inovasi yang dilakukan oleh perusahaan sehingga transfer pengetahuan tidak dapat dilakukan secara cepat.

6) Learning \& Innovation

- Penjelasan APO: proses peningkatan pembelajaran organisasi dan inovasi telah dilakukan, namu perlu dievaluasi dan ditingkatkan kegiatan sosialisasi ke semua unit kerja di perusahaan.

- Hasil survei: beberapa karyawan merasa bahwa ide dan kontribusi mereka terhadap perusahan masih kurang dihargai oleh pimpinan perusahaan.

\section{7) KM Outcomes}

- Penjelasan APO: kinerja organisasi sudah baik, terlihat dari inovasi produk dan peningkatan sistem informasi secara berkelanjutan.

- Hasil survei: kualitas dan inovasi produk dilakukan secara terus menerus guna meningkatkan kinerja dan pendapatan perusahaan.

Adanya hasil penilaian yang kurang maksimal (dalam hal kematangan tingkat pengelolaan pengetahuan perusahaan), kemungkinan disebabkan oleh beberapa faktor, yaitu: (a) kurangnya informasi dan sosialisasi kepada semua karyawan; (b) kurangnya penghargaan terhadap proses berbagi pengetahuan, penciptaan pengetahuan, dan inovasi; (c) pengembangan dan pelatihan yang dilakukan tidak dapat dilakukan secara menyeluruh kepada karyawan; (d) ada kekurangan keahlian yang dimiliki oleh beberapa karyawan dalam menguasai sistem teknologi informasi baru dalam menjalankan kegiatan perusahaan; (e) kurangnya komitmen karyawan dalam berbagi pengetahuan.

Sebagai tolak ukur dalam melihat hubungan antara tingkat kematangan pengelolaan pengetahuan dengan tingkat keberhasilan perusahaan, kita dapat dilihat penilaian kinerja perusahaan yang bersumber dari Laporan Tahunan 2016 tentang Key Performance Indicator/KPI (Tabel 9) - yang mengacu pada Asian Productivity Organization (APO, 2009 ). Pada laporan tersebut dijelaskan bahwa kerangka kerja APO bersifat komprehensif dan memberikan solusi untuk peningkatan kinerja organisasi melalui berbagai elemen pengelolaan pengetahuan.

Tabel 9. Nilai Realisasi Pencapaian KPI

\begin{tabular}{|l|c|c|c|}
\hline \multirow{2}{*}{ Kegiatan } & \multicolumn{3}{c|}{ Nilai KPI } \\
\cline { 2 - 4 } & $\begin{array}{c}\text { Realisasi } \\
2016\end{array}$ & $\begin{array}{c}\text { Target } \\
2016\end{array}$ & $\begin{array}{c}\text { Persentase } \\
(\%)\end{array}$ \\
\hline Keuangan dan pasar & 25.05 & 24.00 & 104,38 \\
\hline Fokus pada pelanggan & 23.10 & 22.00 & 105.00 \\
\hline Efektivitas produk dan proses & 18,56 & 20.00 & 92.80 \\
\hline Fokus tenaga kerja & 16.47 & 17.00 & 96.88 \\
\hline $\begin{array}{l}\text { Kepemimpinan, tata kelola dan tanggung } \\
\text { jawab sosial }\end{array}$ & 15,19 & 17.00 & 89.35 \\
\hline \multicolumn{1}{|c|}{ Total } & 98.37 & 100.00 & 98.37 \\
\hline
\end{tabular}


Tabel 9 menunjukkan bahwa kinerja perusahaan pada tahun 2016 pada kondisi baik. Hal tersebut terlihat dari sektor keuangan dan pasar, serta kegiatan yang berfokus pada realisasi pelanggan melebihi target yang telah ditentukan.

\section{KESIMPULAN}

Melalui pengelolaan pengetahuan dengan APO Assessment Tools, organisasi atau perusahaan dapat meningkatkan kinerjanya melalui pengelolaan pengetahuan yang baik. Pengelolaan pengetahuan organisasi harus berkembang agar mampu beradaptasi dengan perubahan yang terjadi di lingkungan usaha, serta mampu bersaing dalam menjalankan usaha sehingga ada peningkatan pendapatan bagi karyawannya. Analisis pada ketujuh kategori APO Assesment Tools memberikan gambaran bahwa pengelolaan pengetahuan itu sangat penting dan harus didukung setiap karyawan. Untuk itu, perusahaan perlu melakukan inovasi produk dan menyediakaan fasilitas teknologi informasi yang memadai untuk peningkatan kinerja organisasi. Pada penelitian ini, penulis juga merekomendasikan agar perusahaan perkebunan lebih fokus pada pembaruan pengelolaan pengetahuan, yang dilakukan dengan cara: (1) melakukan sosialisasi yang komprehensif kepada seluruh karyawan mengenai pentingnya pengelolaan pengetahuan; (2) membuat komitmen yang jelas dari pemangku kepentingan mengenai insentif karyawan yang memprioritaskan implementasi pengelolaan pengetahuan di perusahaan; (3) mengevaluasi proses dan prosedur pengelolaan pengetahuan yang sudah dilaksanakan; (4) Fokus kegiatan pengelolaan pengetahuan perlu dilakukan lebih lanjut secara intensif ke posisi kepala subbagian dan manajer; (5) dilakukan pemeriksaan berkala pada tingkat kematangan pengelolaan pengetahuan sebagai upaya perbaikan di setiap unit kerja perusahaan. 


\section{DAFTAR PUSTAKA}

Abu, N.S., Al Shobaki, M., \& Abu A.Y. 2016. Knowledge Management Maturity in Universities and its Impact on Performance Excellence "Comparative Study". Journal of Scientific and Engineering Research, 3(4).

Al Shobaki, M.J., Abu, N.S., \& Abu, Y.Y.M. 2016. Promoting Knowledge Management Components in The Palestinian Higher Education Institutions: A Comparative Study. International Letters of Social and Humanistic Sciences, 73, 42-53.

Emilisa, N., Wiguna, A.P., \& Simangunsong, A. 2017. Keterkaitan Proses Manajemen Pengetahuan dengan Kinerja Kerja yang dimediasi oleh Kinerja Manajemen Pengetahuan: Bukti Empiris pada Perusahaan Penyalur Tenaga Kerja Indonesia (TKI). Jurnal Manajemen dan Pemasaran Jasa, 10(1), 117-128.

Hoss, R. \& Schlussel, A. 2009. How Do You Measure the Knowledge Management (KM) Maturity of Your Organization? Metrics That Assess an Organization's KM State. USAWC.1-24.

Hubert, C. \& Lemons, D. 2010. APQC's Levels of Knowledge Management Maturity. APQC. pp 1 $-24$.

Jane O. 2009. Peran Knowledge Management Dalam Meningkatkan Kinerja Perguruan Tinggi. Jurnal Administrasi Bisnis, 5(1), 26-39.

Khatibian, N., Jafari, A.H., \& Pour, G.H. 2010. Measurement of Knowledge Management Maturity Level within Organizations. Business Strategy Series, 11(1), 54 - 70.

Nonaka, I. \& Nishihara, H., Kodama, M., \& Kohlbacher, F. 2013. Dynamic Fractal Organizations for Promoting Knowledge - Based Transformation - A New Paradigm for Organizational Theory. European Management Journal.

Nonaka, I. \& Takeuchi, H. 1995. The Knowledge - Creating Company. New York: Oxford University Press.

North, K. \& Kumta, G. 2018. Knowledge Management: Value Creation through Organizational Learning. Switzerland: Springer.

O'Brien, J. 2013. The Need for a Robust Knowledge Assessment Framework: Discussion and Findings from an Exploratory Case Study. Electronic Journal of Knowledge Management, 93 $-106$.

Ramadhani, S., Tjakraatmadja, H., \& Thoha, N. 2012. Knowledge Management Maturity Level Assessment (Case Study of PT. XYZ). The Indonesian Journal of Business Administration, l(9), 672 - 679.

Rusilowati, U. 2015. Analisis Manajemen Pengetahuan Berbasis Teknologi Informasi. Jurnal Organisasi dan Manajemen, 11(1), 44 - 61.

Sedarmayanti, S. 2017. Perencanaan dan Pengembangan SDM untuk Meningkatkan Kompetensi, Kinerja, dan Produktivitas Kerja. Bandung: Penerbit PT. Refika Aditama.

Sensuse, D. \& Rohajawati, S. 2013. Knowledge Management: Workshop APO Framework, International Journal of Computer Science Issues, 10(2), 25 - 32.

Shaikh, U.M. et al. 2009. Organizational Self Assessment for KM Tools Acquisition and KM Platform. Interdisciplinary Journal of Contemporary Research in Business, 1(3), 62 - 75. 
BACA: Jurnal Dokumentasi dan Informasi, 41 (1) Juni 2020, Halaman : 61-74

Sveiby, E.K. 2001. Knowledge Management - Lessons from the Pioneers. http://www.providersedge.com/docs/km_articles/km_-_lessons_from_the_pioneers.pdf (akses 24 September 2019).

Vestal, W. 2002. Measuring Knowledge Management (KM) Maturity. The American Productivity \& Quality Center (APQC).

Young, R. 2010. Knowledge Management Tools and Techniques Manual.Asian Productivity Organization (APO). Japan: Tokyo. 